\title{
The Properties of Wet Blue Added Crude Enzyme from Rhizopus oligosporus in the Acid Bating Process
}

\author{
A. W. Nugraha ${ }^{a, *}$, O. Suparno ${ }^{b}$, N. S. Indrasti ${ }^{b}$, \& Hoerudin $^{c}$ \\ ${ }^{a}$ Department of Agro-Industrial Technology, Institut Teknologi Sumatera, \\ Jalan Terusan Ryacudu, Way Hui, Jati Agung, South Lampung 35365, Indonesia \\ ${ }^{b}$ Department of Agro-Industrial Technology, Faculty of Agricultural Technology, IPB University \\ Kampus IPB Dramaga, Bogor, West Java 16680, Indonesia \\ 'Indonesian Center for Agricultural Post Harvest Research and Development \\ Jalan Tentara Pelajar No 12 Cibogor, Kecamatan Bogor Tengah, Kota Bogor, West Java 16122, Indonesia \\ *Corresponding author: aditya.nugraha@tip.itera.ac.id \\ (Received 17-03-2021; Revised 12-07-2021; Accepted 04-08-2021)
}

\begin{abstract}
Bating is one of the processes in leather production. This process is generally performed under slightly alkaline conditions, but it can also be done under acidic conditions. Rhizopus oligosporus is categorized as a microorganism that can synthesize acidic enzymes optimally in acidic conditions. This study aimed to evaluate the effect of the bating process using acid protease from $R$. oligosporus on the leather qualities tanned by chromium sulfate. The study used a completely randomized design where crude enzyme activity $\left(0,2.5,5,7.5\right.$, and $\left.10 \mathrm{U} \mathrm{mL}^{-1}\right)$ was a single treatment as an experimental design. Data were analyzed using ANOVA and furtherly tested using Duncan. The results show that the protease synthesized from $R$. oligosporus is potential to be used as a bating agent. The treatment with $2.5 \mathrm{U} \mathrm{mL}^{-1}$ activity was the best treatment in this study to improve leather (wet blue) properties like shrinkage temperature, ash content, and chrome oxide content. The quality of wet blue produced was better than that produced with conventional treatments. It can be concluded that the enzyme activity of $2.5 \mathrm{U} \mathrm{mL}^{-1}$ could be used as a bating-agent alternative in the acid bating stage.
\end{abstract}

Keywords: bating; enzyme activity; leather production; Rhizopus oligosporus

\section{INTRODUCTION}

Bating is one of the process stages in the leathertanning process. This stage is integrated with the deliming stage. The bating process uses enzymes (bating agents) like protease to degrade non-structural proteins, such as albumin, globulin, elastin, and proteoglycan presenting in the pelt after liming and deliming stages (Schropfer et al., 2014). Proteases hydrolyze nonstructural protein to the amino acid. Besides, the bating process also aims to open the collagen fiber networks (Kesarwani et al., 2015; Covington \& Wise, 2019). The bating process affects the quality of produced leather, such as soft and supple properties.

According to Puvanakrishnan et al. (2019) and Biskauskaite et al. (2021), bating can be performed under both alkaline and acid conditions. The bating condition is determined at the deliming process; if it is conducted in alkaline conditions, then the pelt is also conducted in alkaline conditions and vice versa. Nugraha et al. (2020) state that the deliming process can be done under acid conditions and influences the next step, i.e., the bating stage. The bating agent is the main material used during the bating process. The component is enzymes, such as protease and lipase. In conventional bating, the process is performed under alkaline conditions and affected by the deliming stage. If the bating process is conducted under alkaline conditions, the enzyme must be activated in similar conditions. This study conducted bating in an acid condition, while the bating agent was an enzyme (bating agent) synthesized by Rhizopus oligosporus.

$R$. oligosporus is a microorganism that is able to synthesize enzymes. The enzyme is synthesized optimally in a $\mathrm{pH}$ range of 3-7, a temperature of $25-30{ }^{\circ} \mathrm{C}$, and an optimum cultivation period of $72 \mathrm{~h}$ (Rauf et al., 2010; Irfan et al., 2011). It generates enzymes such as protease and lipase (Rauf et al., 2010; Irfan et al., 2011; Singh et al., 2012; Waseem et al., 2018). Particularly in bating stage, protease has an important role in opening the pelt fiber. The acid protease from $R$. oligosporus could work optimum in acidic conditions with a pH of 5.5 (Irfan et al., 2011). That condition follows the deliming stage, which can be carried out under acidic conditions (Nugraha et al., 2020). No further research has been conducted on the bating stage using an enzyme from $R$. oligosporus. Acid bating is not widely practiced. Hence, this study aimed to evaluate the effect of the bating process using acid protease from $R$. oligosporus on the leather qualities tanned by chromium sulfate. 


\section{MATERIALS AND METHODS}

The study was conducted by using a crude enzyme (acid protease) from Rhizopus oligosporus, liming pelt sized of $30 \times 15 \mathrm{~cm}$ from the krupon of the goatskin, lime, sodium sulfide, degreasing agent, tartaric acid, $\mathrm{NaCl}$, sulfuric acid, formic acid, chromium sulfate, and sodium bicarbonate. The tools used include Erlenmeyer, autoclave, HACH UV-Vis spectrophotometer, and other supporting tools. This study was conducted in 3 stages: enzyme production, enzyme application to the pelt as bating agent, and evaluation of pelt and wet blue properties.

The study used a completely randomized design with a single factor which was enzyme activity. The sample was repeated 4 times. Data were analyzed using ANOVA and Duncan's advanced test with a confidence level of $5 \%$. The research procedure is presented in Table 1 . The procedure of presoaking to deliming was adopted from Nugraha et al. (2020).

\section{The Enzyme Production}

$R$. oligosporus from yeast was incubated on potato dextrose agar (PDA) media for 3 days. Then, the spores were propagated into skim media for 3 days. The propagated filtrate was used as a starter to produce the enzyme. The enzyme was synthesized using tofu wastewater that had been sterilized in several Erlenmeyer flasks. The Erlenmeyer flask was put on the shaker at $210 \mathrm{rpm}$, at room temperature $\left(28-30{ }^{\circ} \mathrm{C}\right)$ for 96 hours. Enzyme activity was observed after $24 \mathrm{~h}$ to determine the optimum point of enzyme activity. At the time of enzyme harvesting, the liquid in the Erlenmeyer flask was filtered to obtain the filtrate separated from the hyphae of $R$. oligophorus. The filtrate was centrifuged at $4{ }^{\circ} \mathrm{C}, 4000 \mathrm{rpm}$ for 20 minutes to separate the solids in the filtrate.

\section{The Enzyme Application in Bating Stage}

The enzyme solution (crude enzyme) obtained was applied to the pelt under enzyme activity treatment. Before bating process, the fresh skin was processed, referring to Nugraha et al. (2020) to the deliming stage in acid conditions, and the bating process was also conducted in acid conditions. The doses of crude enzyme used in the bating solution were $0,2.5,5,7.5$, and $10 \mathrm{U}$ $\mathrm{mL}^{-1}$. Then, the pelt was tanned using chromium sulfate. The procedures of soaking to tanning are presented in Table 1.

\section{Enzyme, Pelt, and Wet Blue Properties}

Protease activity. Protease activity was measured using $2.5 \mathrm{~mL}$ of $1 \%(\mathrm{w} / \mathrm{v})$ casein substrate in phosphate buffer at $\mathrm{pH}$ 6.0. Then, $0.5 \mathrm{~mL}$ of enzyme filtrate was added and incubated at $55{ }^{\circ} \mathrm{C}$ for 10 minutes. Afterward, $2.5 \mathrm{~mL}$ of $5 \%$ TCA was added and incubated at a cold temperature for 20 minutes. The reaction mixture was then filtered using filter paper (Whatman No. 1), and the filtrate was measured in a UV-Vis spectrophotometer with a wavelength of $280 \mathrm{~nm}$. Control was made by mixing $2.5 \mathrm{~mL}$ of $1 \%$ casein, $0.5 \mathrm{~mL}$ of distilled water, and $2.5 \mathrm{~mL}$ of $5 \%$ TCA (Castro \& Sato, 2014). One unit (1 U) protease activity is defined as the amount of the enzyme that catalyzes the conversion of one micromole of the substrate (casein) per minute under the specified conditions of the assay method.

Lipase activity. Two grams (2 g) of palm oil and $1 \mathrm{~mL}$ of filtrate enzyme were added into a $150 \mathrm{~mL}$ Erlenmeyer flask. Then, $4 \mathrm{~mL}$ of $0.05 \mathrm{M}$ phosphate buffer solution with a $\mathrm{pH}$ of 7.5 was added. The mixture was stirred for 1 hour. After that, $10 \mathrm{~mL}$ of acetone-alcohol (1:1) was added and mixed until homogeneous. Next, 2-3 drops of PP indicator were added and titrated with $0.05 \mathrm{~N}$

Table 1. The procedure of leather production (wet blue) experiment using crude enzyme in bating stage

\begin{tabular}{|c|c|c|c|}
\hline Processes & Materials & Doses & Remarks \\
\hline \multirow[t]{2}{*}{ Soaking } & Water & $200 \%$ & \multirow[t]{2}{*}{ Drum on $1 \mathrm{~h}$. Drain. } \\
\hline & Degreasing agent (DA) & $0.10 \%$ & \\
\hline \multirow[t]{4}{*}{ Liming } & $\mathrm{Na}_{2} \mathrm{~S}$ & $2.50 \%$ & \multirow{4}{*}{$\begin{array}{l}\text { Drum on } 2 \mathrm{~h} \text {, then on for } 15^{\prime} \text {, off for } 45^{\prime} \text {, repeatedly until } 6 \mathrm{~h} \text {. Overnight } \\
\text { and then drain. Pelt wash with } 150 \% \text { water }\end{array}$} \\
\hline & $\mathrm{Ca}(\mathrm{OH})_{2}$ & $10 \%$ & \\
\hline & DA & $0.10 \%$ & \\
\hline & Water & $300 \%$ & \\
\hline \multirow[t]{3}{*}{ Deliming } & Ammonium sulfate ${ }^{a}$ & $2.50 \%$ & \multirow{3}{*}{$\begin{array}{l}\text { a was a conventional process, deliming time } 60^{\prime} \text {. } \\
\text { b was research experimental. The } \mathrm{pH} \text { was } 5 \text { and deliming time } 60^{\prime}\end{array}$} \\
\hline & Tartaric acid ${ }^{b}$ & $0.84 \%$ & \\
\hline & Water & $0.10 \%$ & \\
\hline \multirow[t]{3}{*}{ Bating } & Alkaline bate ${ }^{\mathrm{a}}$ & $300 \%$ & \multirow{3}{*}{$\begin{array}{l}\text { a was an enzyme that was used in the conventional process. } \\
\text { b enzyme that was used in the experiment. } \\
\text { The bating duration was } 45^{\prime} \text {. Then drain and wash the pelt. }\end{array}$} \\
\hline & Enzyme from rhizopus & & \\
\hline & oligosporus $^{\mathrm{b}}$ & & \\
\hline \multirow[t]{4}{*}{ Pickling } & Water & $100 \%$ & \multirow{4}{*}{$\begin{array}{l}\text { Water and } \mathrm{NaCl} \text { were added together. Drum on } 20^{\prime} \text {. Then, other ma- } \\
\text { terials were added periodically with an interval of } 15^{\prime} \text {. The } \mathrm{pH} \text { of the } \\
\text { pelt was } 3 .\end{array}$} \\
\hline & $\mathrm{NaCl}$ & $10 \%$ & \\
\hline & Formic acid & $0.60 \%$ & \\
\hline & Sulfuric acid & $0.40 \%$ & \\
\hline \multirow[t]{2}{*}{ Tanning } & Chromium sulfate & $8 \%$ & \multirow{2}{*}{$\begin{array}{l}\text { Chromium sulfate was added, Drum on } 1 \mathrm{~h} \text {. Sodium bicarbonate } \\
\text { was added, drum on } 6 \mathrm{~h} \text {. Drain and wash the wet blue. Aging and } \\
\text { toggling. }\end{array}$} \\
\hline & Sodium bicarbonate & $1.20 \%$ & \\
\hline
\end{tabular}


$\mathrm{KOH}$ in alcohol. The titration was terminated when the solution's color turned pink and persisted, and then the titration volume was documented. The control solution was prepared as the same way as the sample treatment, but the acetone-alcohol solution (1:1) was added at 0 $\mathrm{h}$, before stirring, to inactivate the enzyme (Sumarlin et al., 2013). One unit (1 U) lipase activity is defined as the amount of the enzyme that catalyzes the conversion of one micromole of the substrate (lipid) per minute under the specified conditions of the assay method.

Dissolved protein content. The Bradford test was carried out to determine the concentration of dissolved protein in the solution before and after the bating with Bovine Serum Albumin (BSA) as a standard. The Bradford solution was prepared using $10 \mathrm{mg}$ of Coomassie Brilliant Blue (CBB) with $5 \mathrm{~mL}$ of $95 \%$ ethanol mixed with $10 \mathrm{~mL}$ of $85 \%$ phosphoric acid and distilled water until the volume reached $500 \mathrm{~mL}$. The Bradford solution was then filtered using filter paper. The determination of dissolved protein in this method was measured using a spectrophotometer at a wavelength of $595 \mathrm{~nm}$ (Bradford, 1976). A sample of $0.01 \mathrm{~mL}$ filtered bate solution was added with $1.99 \mathrm{~mL}$ of distilled water and then mixed using a vortex mixer. Bradford solution at a volume of $5 \mathrm{~mL}$ was added to the sample and homogenized. Afterward, the sample was assessed with a spectrophotometer.

Fat content. A total of $1 \mathrm{~L}$ of the sample was acidified using $5 \mathrm{~mL}$ of $1: 1 \mathrm{HCl}$ or $1: 1 \mathrm{H}_{2} \mathrm{SO}_{4}$ to create $\mathrm{pH} 2$ conditions. The acid sample was transferred to a separating funnel. A $30 \mathrm{~mL}$ of hexane was added to the sample bottle for rinsing. Then, the solvent was transferred to a separating funnel. A total of 129 separating funnels were shaken vigorously for 2 minutes and then let stand to separate the layers. The water layer in the sample was removed, and the remaining organic layer was transferred into the fat flask. Draining of the organic layer was carried out through a funnel containing filter paper and $10 \mathrm{~g} \mathrm{Na}_{2} \mathrm{SO}_{4}$.

Furthermore, the separation tube and funnel were rinsed with hexane solvent until clean. The fat flask was then distilled at $85{ }^{\circ} \mathrm{C}$ with an adapter at the end to condense the evaporated solvent. When visible solvent condensation stopped, the distiller was replaced with a vacuum adapter, and immediately the sample was vacuumed through the flask for 1 minute. The flask was removed from the bath, and the surface was wiped to remove moisture. The flask was cooled in a desiccator until a stable weight was obtained (APHA, 2017).

Pelt morphology. The pelt was cut into small pieces $(6.5 \mathrm{~cm} \times 1 \mathrm{~cm})$ with $1.5 \mathrm{~mm}$ thick before and after being treated. Then, the pelt morphology of samples was observed and analyzed using a JEOL JSM-IT200 Scanning Electron Microscope. The magnification performed was 200 times (Taylor et al., 2013).

Total ash content. The sample at a weight of $1 \mathrm{~g}$ was put in a porcelain dish and burned until it did not smoke. Then, the sample was ignited in a furnace at 600
${ }^{\circ} \mathrm{C}$ for 4 hours. Afterward, the sample was weighed, and the ash content was calculated (AOAC, 2019).

Shrinkage temperature. Wet blue $(0.5 \times 5 \mathrm{~cm})$ was attached to the holder and then put into a glass filled with $350 \pm 50 \mathrm{~mL}$ of white oil. The water or white oil was heated, and the temperature rising was preserved to 3 ${ }^{\circ} \mathrm{C}$ per minute. White oil has a boiling point above 100 ${ }^{\circ} \mathrm{C}$ and was used to test samples tanned using chrome. The first temperature when shrinkage occurred was documented (SLTC, 1996).

Chrome oxide content. An amount of $1 \mathrm{~g}$ of leather (full chrome) was burned to produce ash using a furnace in a few hours. Then, the ashes were put in a funnel flask or a Kjeldahl flask. About $5 \mathrm{~mL}$ of sulfuric acid and $10 \mathrm{~mL}$ of perchloric acid were added. The mixture was heated in a wire burner to boil. A small funnel was placed around the neck of the pumpkin to avoid splashes. The reaction started when the color changed to orange, and then the fire was lowered. Once the color change was completed, the sample was heated for 2 minutes. Later, the sample was cooled for a while in the air and cooled in cold water. Then, the sample was diluted to $200 \mathrm{~mL}$. To remove the chlorine that was formed, the sample was boiled for 10 minutes. After cooling, $15 \mathrm{~mL}$ of orthophosphoric acid and $20 \mathrm{~mL}$ of the potassium iodide solution were added to cover any iron and let stand for 10 minutes in the dark. Then, the sample was titrated with $0.1 \mathrm{~N}$ of sodium thiosulfate until the flask was light green by adding $5 \mathrm{~mL}$ of starch indicator solution (SLTC, 1996).

\section{RESULTS}

\section{Crude Enzyme Activity}

The result showed that the protease and lipase enzymes had similar activities. Both protease and lipase activities were increased from $0 \mathrm{~h}$ and reached peaks at $72 \mathrm{~h}$ after treatment (Figure 1). Then, the enzyme activities showed a decreased response after $72 \mathrm{~h}$. This decreased activity could be due to the depletion of nutrients in the substrate or the presence of inhibiting factors during the synthesis of the enzymes by $R$. oligoporus. Then, the crude enzyme from $R$. oligoporus was used as a bating agent in the acid bating stage.

\section{Dissolved Protein and Fat Content in Bating Solution}

The result of dissolved protein content is presented in Table 2. The highest dissolved protein content was found at $10 \mathrm{U} \mathrm{mL}^{-1}$ of enzyme activity by $211.67 \mathrm{mg} \mathrm{L}^{-1}$, while the lowest dissolved protein content was found at $0 \mathrm{U} \mathrm{mL} \mathrm{m}^{-1}$ of enzyme activity by $13.33 \mathrm{mg} \mathrm{L}^{-1}$. Treatment with $5 \mathrm{U} \mathrm{mL}^{-1}$ of enzyme activity showed a higher dissolved protein content than the conventional treatment (121.67 mg L-1 vs. $92.08 \mathrm{mg} \mathrm{L}^{-1}$ ) and was significantly different. Furthermore, the treatment of $7.5 \mathrm{U} \mathrm{mL}^{-1}$ and $10 \mathrm{U} \mathrm{mL}^{-1}$ of enzyme activities showed higher dissolved proteins as much as $167.50 \pm 6.87 \mathrm{mg} \mathrm{L}^{-1}$ and $211.67 \pm$ $6.38 \mathrm{mg} \mathrm{L}^{-1}$, respectively. Both levels of enzyme activities 


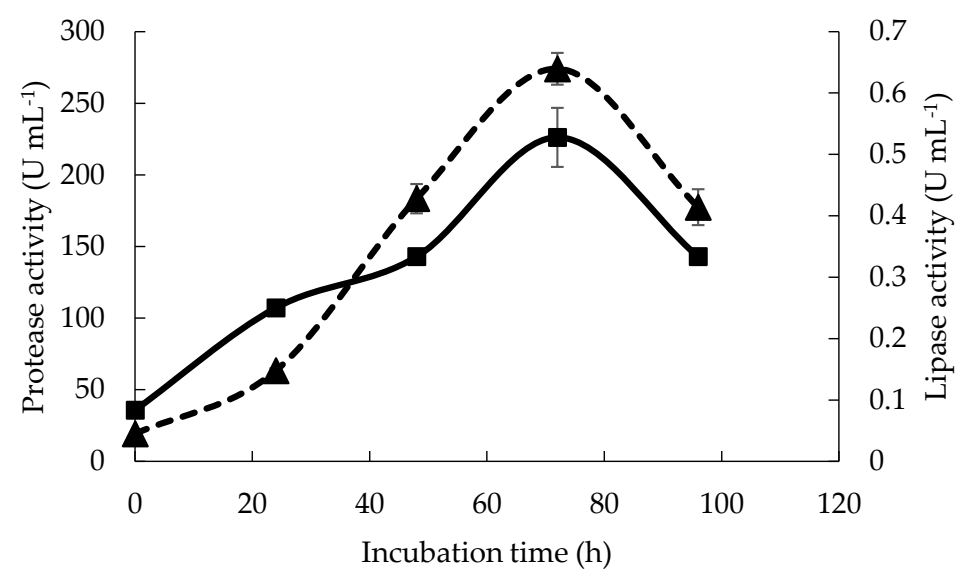

Figure 1. The protease and lipase activities during the enzyme production process using tofu whey within the time of $0-96 \mathrm{~h}$ ( $\Delta$ protease; $\boldsymbol{\|}$ lipase $)$

had significantly different results compared with treatment with $5 \mathrm{U} \mathrm{mL}^{-1}$ of enzyme activity.

The study result shows that the enzyme activity significantly affected fat content (Table 2). The enzyme activities of 0 to $7.5 \mathrm{U} \mathrm{mL}^{-1}$ were significantly different from conventional treatment; meanwhile, $10 \mathrm{UmL}^{-1}$ of enzyme activity was not significantly different from conventional treatment.

Table 2 shows the enzyme activity affected both the dissolved protein and fat contents in bating solution. In addition, a similar effect was also shown from the micrograph of the scanning electron microscope in Figure 2. Enzyme activity significantly influenced the structure of pelt fiber after the bating stage. The opening of the pelt fiber network was observed in each treatment, and the higher enzyme activity resulted in a more excellent opening of the pelt fiber network.

\section{Physical and Chemical Properties of Wet Blue}

Ash content. The highest total ash content in wet blue was $5.54 \pm 0.11 \%$ in $10 \mathrm{U} \mathrm{mL}^{-1}$ of enzyme activity (Table
3). The rise of crude enzyme activity added the total ash content in the wet blue. Duncan's test shows crude enzyme activity had a significant effect on total ash content. The $0 \mathrm{U} \mathrm{mL}^{-1}$ and $2.5 \mathrm{U} \mathrm{mL}^{-1}$ of enzyme activities were significantly different, but $2.5 \mathrm{U} \mathrm{mL}^{-1}$ and $5 \mathrm{U} \mathrm{mL}^{-1}$ of enzyme activities were found to be not significantly different. Furthermore, the $5 \mathrm{U} \mathrm{mL}^{-1}$ and $7.5 \mathrm{U} \mathrm{mL}^{-1}$ of enzyme activities were also not significantly different.

Table 2. Dissolved protein and fat content in the bating solution with various levels of protease activity

\begin{tabular}{ccc}
\hline $\begin{array}{c}\text { Protease activity } \\
\left(\mathrm{U} \mathrm{mL}^{1-}\right)\end{array}$ & $\begin{array}{c}\text { Dissolved protein } \\
\text { content }\left(\mathrm{mg} \mathrm{L}^{1-}\right)\end{array}$ & Fat content $\left(\mathrm{mg} \mathrm{L}^{1-}\right)$ \\
\hline 0 & $13.33 \pm 0.00^{\mathrm{a}}$ & $56.00 \pm 3.92^{\mathrm{a}}$ \\
2.5 & $55.00 \pm 4.30^{\mathrm{b}}$ & $88.50 \pm 8.10^{\mathrm{b}}$ \\
5 & $121.67 \pm 9.62^{\mathrm{d}}$ & $165.50 \pm 8.43^{\mathrm{c}}$ \\
7.5 & $167.50 \pm 6.87^{\mathrm{e}}$ & $241.25 \pm 12.07^{\mathrm{d}}$ \\
10 & $211.67 \pm 6.38^{\mathrm{f}}$ & $305.25 \pm 14.18^{\mathrm{e}}$ \\
Conventional & $92.08 \pm 8.54^{\mathrm{c}}$ & $318.00 \pm 24.25^{\mathrm{e}}$ \\
\hline
\end{tabular}

Note: Means in the same column with different superscripts differ significantly $(\mathrm{p}<0.05)$.

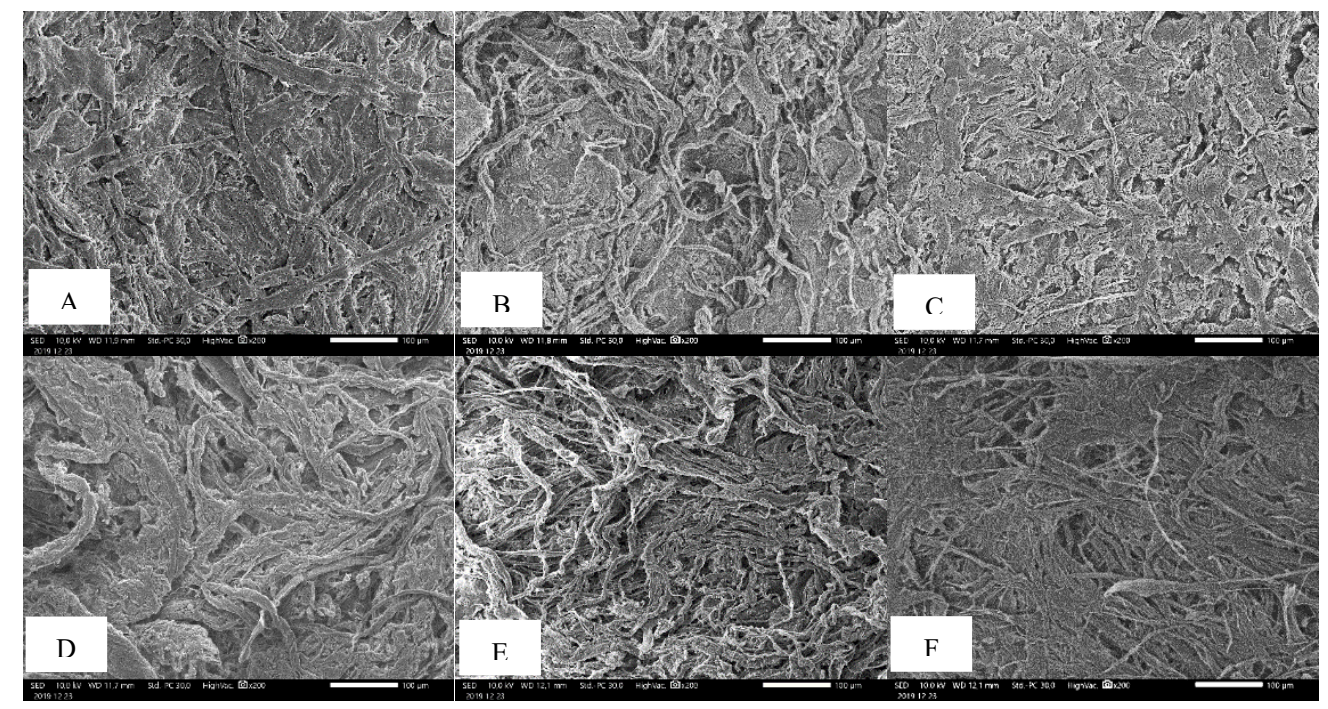

Figure 2. Micrograph of scanning electron microscope of the pelt after being treated by various levels of protease activity $\left(\mathrm{A}=0 \mathrm{U} \mathrm{mL}^{-1}, \mathrm{~B}=2.5 \mathrm{U} \mathrm{mL}^{-1}, \mathrm{C}=5 \mathrm{U} \mathrm{mL}^{-1}, \mathrm{D}=7.5 \mathrm{U} \mathrm{mL}^{-1}, \mathrm{E}=10 \mathrm{U} \mathrm{mL}^{-1}\right.$, and $\mathrm{F}=$ conventional). 
The other level of the study also showed the conventional treatment was not significantly different from $0 \mathrm{U}$ $\mathrm{mL}^{-1}$ of enzyme activity.

Chrome oxide content. The data analysis of chrome oxide content is shown in Table 3. The result shows that the increased activity of the enzymes also increased the chromium oxide content in wet blue. The enzyme activity of $10 \mathrm{U} \mathrm{mL}^{-1}$ was the treatment with the highest chromium oxide content (3.56 $\pm 0.11 \%$ ) (Figure 3 ). Meanwhile, the lowest chromium oxide content was found in the $0 \mathrm{U} \mathrm{mL}^{-1}$ enzyme activity $(2.42 \pm 0.09 \%)$. Further analysis shows that each level had significant differences, but $5 \mathrm{U} \mathrm{mL}^{-1}$ and $7.5 \mathrm{U} \mathrm{mL}^{-1}$ of enzyme activities were not significantly different.

Shrinkage temperature. The result shows that the enzyme activity greatly affected the shrinkage temperature of the wet blue. In Table 3 , the $0 \mathrm{U} \mathrm{mL}^{-1}$ of enzyme activity was significantly different from the other levels. Meanwhile, the $2.5 \mathrm{U} \mathrm{mL}^{-1}$ of enzyme activity was not significantly different from $5 \mathrm{U} \mathrm{mL}^{-1}$ and $7.5 \mathrm{U} \mathrm{mL}^{-1}$. The enzyme activity of $10 \mathrm{U} \mathrm{mL}^{-1}$ was significantly different from $0 \mathrm{U} \mathrm{mL}^{-1}$ and $2.5 \mathrm{U} \mathrm{mL}^{-1}$ but was not significantly different from the enzyme activity of $5 \mathrm{U} \mathrm{mL}^{-1}$ and $7.5 \mathrm{U}$ $\mathrm{mL}^{-1}$. Further analysis shows that all levels showed significant differences with conventional treatment, except $0 \mathrm{U} \mathrm{mL}^{-1}$ (Figure 3).

\section{DISCUSSION}

\section{Crude Enzyme Activity}

The optimum time in Figure 1 followed Rauf et al. (2010), who found that the optimum time for enzyme synthesis from $R$. oligosporus occurred at $72 \mathrm{~h}$ for protease. Besides, Irfan et al. (2011) showed similar optimum times in R. oligosporus for protease. In the other Rhizopus species, such as Rhizopus oryzae, the optimum time for enzyme synthesis occurred at an incubation period of 168 h (Mushtaq et al., 2015). Meanwhile, the study by Nahas (1988) presented the optimum time for enzyme synthesis from $R$. oligosporus was between $72-96 \mathrm{~h}$ for lipase. The optimum lipase activity from $R$. oligosporus EM-7 was $64 \mathrm{~h}$, but under neutral conditions (Waseem et al., 2018).

At the optimum point, the protease activity in this study reached $274.09 \pm 11.10 \mathrm{U} \mathrm{mL}^{-1}$ and the lipase activity was $0.53 \pm 0.05 \mathrm{U} \mathrm{mL}^{-1}$. In the other study, the protease activity of various types of Rhizopus sp showed different results at their optimum conditions. Research by M'hir et al. (2012) showed the highest protease activity on wheat gluten substrate was $258.2 \mathrm{U} \mathrm{mL}^{-1}$ using $R$. oryzae. Meanwhile, the study result from Vaseghi et al. (2013) showed the lipase activity from $R$. oryzae was 52-215 Ugds ${ }^{-1}$ using sugarcane bagasse as a substrate.

Table 3. Physical and chemical wet blue properties treated by various levels of protease activity

\begin{tabular}{ccccc}
\hline Protease activity $\left(\mathrm{U} \mathrm{mL}^{1-}\right)$ & Total ash content $(\%)$ & Ash content non $\mathrm{Cr}_{2} \mathrm{O}_{3}(\%)$ & $\mathrm{Cr}_{2} \mathrm{O}_{3}$ content $(\%)$ & Shrinkage temperature $\left({ }^{\circ} \mathrm{C}\right)$ \\
\hline 0 & $4.35 \pm 0.28^{\mathrm{a}}$ & $1.92 \pm 0.19$ & $2.42 \pm 0.09^{\mathrm{a}}$ & $98.00 \pm 0.82^{\mathrm{a}}$ \\
2.5 & $4.98 \pm 0.09^{\mathrm{c}}$ & $1.97 \pm 0.10$ & $3.01 \pm 0.01^{\mathrm{c}}$ & $100.38 \pm 0.75^{\mathrm{b}}$ \\
5 & $5.19 \pm 0.08^{\mathrm{cd}}$ & $1.97 \pm 0.17$ & $3.21 \pm 0.18^{\mathrm{d}}$ & $101.25 \pm 1.26^{\mathrm{bc}}$ \\
7.5 & $5.31 \pm 0.23^{\mathrm{de}}$ & $1.98 \pm 0.04$ & $3.34 \pm 0.24^{\mathrm{d}}$ & $101.38 \pm 0.75^{\mathrm{bc}}$ \\
10 & $5.54 \pm 0.11^{\mathrm{e}}$ & $1.98 \pm 0.07$ & $3.56 \pm 0.11^{\mathrm{e}}$ & $102.38 \pm 0.48^{\mathrm{c}}$ \\
Conventional & $4.67 \pm 0.12^{\mathrm{b}}$ & $1.90 \pm 0.18$ & $2.77 \pm 0.12^{\mathrm{b}}$ & $99.00 \pm 1.16^{\mathrm{a}}$ \\
Standard & - & Max. 2.00 & Min. $2.50 \%$ & - \\
\hline
\end{tabular}

Note: Means in the same column with different superscripts differ significantly $(p<0.05)$.

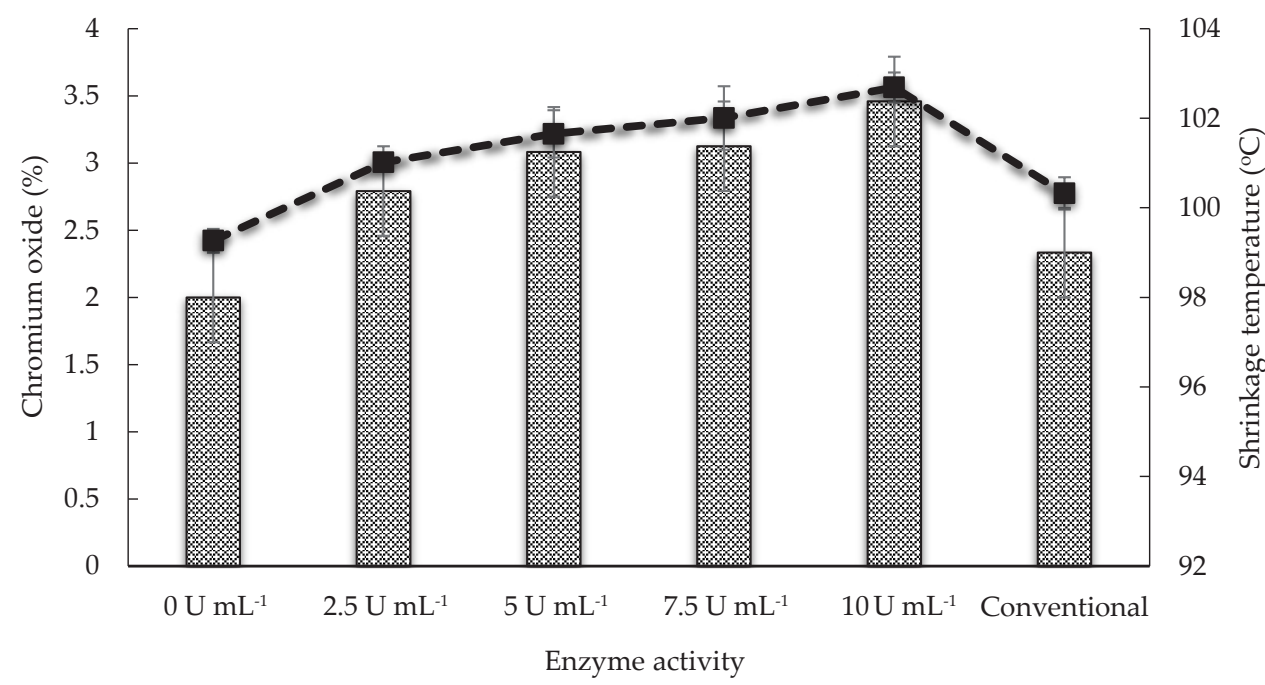

Figure 3. Effect of enzyme activity on the chromium oxide content and leather shrinkage temperature (wet blue).

$\boldsymbol{x}$ shrinkage temperature $\mathbf{c h r o m e}$ oxide. 
The enzyme was synthesized when Rhizopus sp. utilized complex substrate as nutrition to grow (Lennartsson et al., 2014). The differences in protease and lipase activity in various study results were caused by several factors: the substrate, inhibitor, activator, $\mathrm{pH}$, temperature, inducer, Rhizopus type, and several other factors. According to Ullah et al. (2019), the addition of nutrients to the media greatly affects the enzymes produced. Meanwhile, the inducer, carbon, and nitrogen also influence the synthesis of the enzyme type to be obtained (Chhaya \& Gupte, 2013; Cheba et al., 2017; Cheba et al., 2018). This is also supported by Sharma \& Singh (2016), stating that increasing the amount of nitrogen and decreasing carbon can suppress protease.

\section{Dissolved Protein and Fat Content in the Bating Solution}

The bating stage aims to degrade the non-structural or non-collagen proteins present in the pelt (Covington $\&$ Wise, 2019). The degradation or protein hydrolysis process in the pelt causes the protein to break down into its monomers and be released from the pelt. The monomers are identified as dissolved proteins.

The result showed that the higher protease activity used led to higher dissolved protein content in the bating solution (Table 3). This exhibited that the enzyme was working properly and hydrolyzed the nonstructural proteins found in the pelt. The analysis conducted by Hidayati et al. (2015) also showed an increase in the dissolved protein content with an increase in the concentration of tempeh yeast used. Besides, Song et al. (2019) study shows that enzymes affect the total protein formed after the bating process. The higher enzyme used causes a higher total protein formed. Hidayati et al. (2015) showed that bating time also affects the dissolved protein produced. The bating time is similar to the contact time between the substrate and the enzymes. The longer the contact or reaction time in the bating stage caused the increased protein mass transfer from the pelt to the bating solution (Song et al., 2019).

One of the goals of the bating stage is to hydrolyze non-structural protein. The bating stage increases the active carboxyl group in the pelt and creates more chromium bonding in collagen. According to Karmini et al. (1999), the protease helps to remove fibrils in the pelt, resulting in the elastic and supple properties due to the depolymerization of collagen fibers, which opens these fibers.

Fat is one of the components found in the pelt. This compound is not expected in the leather tanning process because it inhibits the penetration of chemicals into the pelt (Nasr, 2017). According to Zengin \& Afsar (2011), fats or lipids in the skin/hide can cause uneven tanning. It obstructs hydrophilic chemicals from penetrating into the pelt. Moreover, the fat contained in the pelt also affects the quality of the final leather product, such as blemishes, odors, and hardness. To prevent damage to the end product of the wet blue, fat should be removed. The fat removal process is performed using lipase. Lipase hydrolyzes fats and oils in the pelt (de Souza \&
Gutterres, 2012). The analysis of the bating solution is conducted to measure the fat that has been removed during the bating process.

The enzyme synthesized from $R$, oligosporus contains a low activity of lipase. The higher protease activity increases the lipase activity. The increase of lipase activity is more effective in hydrolyzing fat. This study shows the highest fat content in the bating solution was found at $10 \mathrm{U} \mathrm{mL}^{-1}$ of enzyme activity; meanwhile, the lowest fat content was found at $0 \mathrm{U} \mathrm{mL}^{-1}$ of enzyme activity. The increased fat content in the bating solution was correlated with the increasing crude protease activity used. The presence of fat in the bating solution was due to the hydrolysis activity of lipase, even in small activities.

Table 3 shows that the fat content in the bating solution was higher than the dissolved protein content even though the lipase activity was lower than the protease activity. This result was probably due to the physical impact of the pelt with the tannery drum, which pushed the fat out of the pelt tissue more easily due to the opening of collagen fibers by protease.

The enzyme changes the structure of the pelt. Figure 2 shows pelt fibers were opened after the bating stage. Crude enzyme activity affected the fiber opening in a dose-dependent manner. The increased crude enzyme activity caused an increase in the fiber opening in the pelt. The opening provides an opportunity for the tanner material to bind to carboxyl groups and amine groups in the skin collagen. The fiber opening also influences the leather quality, such as tear strength, tensile strength, and elongation at break.

\section{Physical and Chemical Properties of Wet Blue}

Ash content. This study shows that the enzyme activity affected the ash content of the wet blue. The higher protease activity increased levels of ash formed (Table 3 ). The enzymes degrade non-collagen proteins in the pelt and form functional groups that bind to mineral tanning agents (chromium sulfate) during the tanning process. This finding was supported by the study of Hidayati et al. (2015) showed that the increase of concentration of tempeh yeast also increased the ash content of the leather.

The ash content indicates the inorganic compounds in leather. Several factors cause high ash content in the leather, such as the presence of mineral tanning agents and the lime content that remains in the skin. Chromium sulfate was the tanning agent used in this study that contributed to the high ash content in the wet blue. According to BSN (2011), the maximum ash content of leather is $2 \%$ after deducting the chromium oxide levels. If the ash content exceeds $2 \%$ after deducting the chromium oxide content, it may occur due to the other minerals in the leather. The potential mineral contained in the wet blue is calcium due to lime $\left(\mathrm{Ca}(\mathrm{OH})_{2}\right)$ during the liming process before tanning. The incomplete deliming stage affects the amount of ash formed. In this study, the ash content after deducting the chromium oxide on the leather had met the predetermined standards. 
Chrome oxide content. Chrome oxide is one of the required parameters in the leather tanning process. The high content of chromium oxide in the wet blue affects the shrinkage temperature of the wet blue. The chromium compound binds covalently with the collagen carboxylate group. An increase in the covalent bonds formed causes higher wet blue shrinkage temperature (Covington \& Wise, 2019). Increased levels of chromium oxide in the leather are caused by enzyme activity during the bating process. Enzymes hydrolyze non-collagen proteins are found in leather (Al Mamun et al., 2015). The hydrolysis opens the collagen fibers and forms more active carboxyl groups. The number of these groups encourages higher covalent bond formation between the tanning material and the carboxyl groups. Thus, this active carboxyl group is very important in creating bonding between tanning agents and collagen.

Shrinkage temperature. Enzyme activity in the bating process affects the shrinkage temperature of the leather. Higher enzyme activity causes a higher shrinkage temperature. Enzyme activity as a hydrolyzing agent opens the skin fibers to form active carboxyl groups. More carboxyl groups form more bonding between the chromium and the carboxyl groups in collagen. The covalent bonds between the chromium and carboxylate groups cause a high shrinkage temperature of the leather (Covington \& Wise, 2019). According to Mann \& McMillan (2017), covalent bonds in tanning are very strong and able to withstand heat up to temperatures above $100^{\circ} \mathrm{C}$. Meanwhile, the increased shrinkage temperature and chrome oxide content in the leather indicates that the process is successful.

The shrinkage temperature in the chrome tanning process is related to the chromium oxide content in the leather. According to Hasan et al. (2014) and Nugraha et al. (2019), the level of chromium oxide in the wet blue affects the shrinkage temperature of the leather in a linear relationship. Higher chromium oxide contained in the wet blue produces a higher shrinkage temperature.

All treatments showed good physical and chemical properties. It met with BSN standards and was better than conventional treatment. The higher enzyme activity treatments also exhibited great results, but according to physical and chemical properties, the protease activity with $2.5 \mathrm{U} \mathrm{mL}^{1-}$ was the best treatment. Lower enzyme activity was preferred as it would certainly reduce the use of enzymes and operating costs.

\section{CONCLUSION}

The crude enzyme produced by Rhizopus oligosporus can be used in the acid bating process and eliminates the use of conventional enzymes. The effects were increasing the dissolved protein content and fat content in bating solution, and also the pelt fiber network was more open when the enzyme activity was higher. Treatment with a $2.5 \mathrm{U} \mathrm{mL}^{-1}$ was the best treatment because the physical and chemical quality had met BSN standards and was above the quality of the conventional treatment.

\section{CONFLICT OF INTEREST}

The researchers state that there is no conflict of interest with any personal, financial, or other relationships with other people or organizations related to the material discussed in the manuscript.

\section{ACKNOWLEDGEMENT}

We highly appreciate Indonesia's Ministry of Research, Technology, and Higher Education for its research funding and support in accelerating the master's program leading to doctorate research grant (PMDSU) with contract number: 1530/IT3.11/PN/2018.

\section{REFERENCES}

Al Mamun, M. A., M. M. Khan, M. N. R. Akand, S. N. Khan, \& M. M. Hoq. 2015. Characterization of an alkaline protease with high quality bating potential in leather processing from bacillus licheniformis MZK05M9 mutant. Int. J. Biol. Res. 3:36-41. https://doi.org/10.14419/ijbr.v3i1.4250

AOAC. 2019. Official methods of analysis of AOAC international $21^{\text {st }}$ ed. AOAC International. Gaithersburg, Maryland.

APHA. 2017. Standard Methods for The Examination of Water and Wastewater. 23 ${ }^{\text {th }}$ ed. APHA, AWWA, WPCF, Washington.

Biskauskaite, R., V. Valeikiene, \& V. Valeika. 2021. Enzymes for leather processing: effect on pickling and chroming. Mater 14:1-11. https://doi.org/10.3390/ma14061480

Bradford, M. M. 1976. A rapid and sensitive method for the quantitation of microgram quantities of protein utilizing the principle of protein-dye binding. Anal. Biochem. 72:248-254. https://doi.org/10.1016/0003-2697(76)90527-3

BSN (Badan Standarisasi Nasional). 2011. SNI 4593:2011 Kulit Jaket Domba/Kambing. BSN, Jakarta. (In Indonesian)

Castro, R. J. S. \& H. H. Sato. 2014. Protease from Aspergillus oryzae: Biochemical characterization and application as a potential biocatalyst for production of protein hydrolysates with antioxidant activities. J. Food Process. 2014:1-11. https://doi.org/10.1155/2014/372352

Cheba, B. A., T. I. Zaghloul, A. R. El-Mahdy, \& M. H. ElMasrry. 2017. Effect of carbon sources on Bacillus sp. R2 chitinase production. Adv. Environ. Biol. 11:75 - 80.

Cheba, B. A., T. I. Zaghloul, A. R. El-Mahdy, \& M. H. ElMasrry. 2018. Effect of nitrogen sources and fermentation conditions on Bacillus sp R2 chitinase production. Procedia Manuf. 22:280-287. https://doi.org/10.1016/j. promfg.2018.03.043

Chhaya, U. \& A. Gupte. 2013. Effect of different cultivation conditions and inducerson the production of laccase by the litter-dwelling fungalisolate Fusarium incarnatum LD-3 under solidsubstrate fermentation. Ann. Microbol. 63:215223. https://doi.org/10.1007/s13213-012-0464-1

Covington, A. D. \& W. R. Wise. 2019. Tanning Chemistry: The Science of Leather. $2^{\text {nd }}$ ed. RSC Publising, UK. https://doi. org/10.1186/s42825-020-00041-0

De Souza, F. R. \& Gutterres. 2012. Application of enzymes in leather processing: a comparison between chemical and coenzymatic processes. Braz. J. Chem. Eng. 29:473-481. https://doi.org/10.1590/S0104-66322012000300004

Hasan, E. A., M. T. Ibrahim, \& K. A. Sally. 2014. Optimisation of chrome retanning process to the garad (Acacia nilotica) tanned leather. J. Agric. Vet. Sci. 15:87-94.

Hidayati, A., P. H. Riyadi, \& L. Rianingsih. 2015. The effect of bating agent from ragi tempe (Rhizopus oligosphorus) to the 
quality of nila (Oreochromis niloticus) leather. Indonesian Journal of Fisheries Science and Technology 11:26-33.

Irfan, M., A. Rauf, Q. Syed, M. Nadeem, \& S. Baig. 2011. Exploitation of different agro-residues for acid protease production by Rhizopus sp in koji fermentation. IJAVMS 5:43-52. https://doi.org/10.5455/ijavms.20110215080443

Karmini, N. R., C. Hemachender, J. G. S. Mala, \& R. Puvanakrishnan. 1999. Microbial enzyme technology as an alternative to conventional chemical in leather industry. Curr. Sci. 77:80-86.

Kesarwani, P., S. Jahan, \& K. Kesarwani. 2015. A review of leather processing. Int. J. Appl. Res. 1:977-982.

Lennartsson, P. R., M. J. Taherzadeh, \& L. Edebo. 2014 Rhizopus. In: C. A. Batt, M. L. Tortorello (Eds). Encyclopedia of Food Microbiology (Second edition). Academic Press, Cambridge. p. 284-290. https://doi.org/10.1016/ B978-0-12-384730-0.00391-8

M'hir, S., A. Mejri, I. Sifaoui, M. B. Slama, M. Mejri, P. Thonart, \& M. Hamdi. 2012. Improvment of protase production by Rhizopus oryzae $\mathrm{CH} 4$ grown on wheat gluten using response methodology and its scale-up in a bioreactor. Arch. Appl. Sci. Res. 4:1110-1116.

Mann, B. R. \& M. M. McMillan. 2017. The chemistry of leather industry. https://nzic.org.nz/app/uploads/2017/10/5C.pdf.

Mushtaq, Z., M. Irfan, M. Nadeem, M. Naz, \& Q. Syed. 2015. Kinetics study of extracellular detergent stable alkaline protease from Rhizopus ozyzae. Braz. Arch. Biol. Technol. 58:175-184. https://doi.org/10.1590/S1516-8913201400071

Nahas, E. 1998. Control of lipase production by Rhizopus oligosporus under various growth conditions. J. Gen. Microbiol. 134:227-233. https://doi.org/10.1099/00221287-134-1-227

Nasr, A. I. 2017. Reusing limed fleshing wastes as a fatliquoring in leather processing. Egypt J. Chem. 60:919-928.

Nugraha, A. W., O. Suparno, \& N. S. Indrasti. 2019. Water reuse strategy in leather tannery process. Int. J. Recent Technol. Eng. 7:958-964.

Nugraha, A. W., O. Suparno, N. S. Indrasti, \& Hoerudin. 2020. Free ammonia deliming: effect of tartaric addition as a deliming agent on the quality of wet blue and wastewater. Trop. Anim. Sci. J. 43:176-182. https://doi.org/10.5398/ tasj.2020.43.2.176

Puvanakrishnan, R., S. Sivasubramanian, \& T. Hemalatha. 2019. Microbial Technology: Concepts and Applications. MJP Publishers, Chennai - India.
Rauf, A., M. Irfan, M. Nadeem, I. Ahmed, \& H. M. N. Iqbal. 2010. Optimization of growth conditions for acidic protease production from Rhizopus oligosporus through solid state fermentation of sunflower meal. World Acad. Sci. Eng. Technol. 4:608-611.

Schropfer, M., E. Klurer, \& M. Meyer. 2014. Influence of elastin degradation on the mechanical properties of leather. J. Am. Leather Chem. Assoc. 109:306-313.

Sharma, A. K. \& S. P. Singh. 2016. Effect of amino acids on the repression of alkaline protease synthesis in haloalkaliphilic Nocardiopsis dassonvillei. Biotechnol. Rep. 12:40-51. https://doi.org/10.1016/j.btre.2016.10.004

Singh, A. K., \& M. Mukhopadhyay. 2012. Overview of fungal lipase: a review. Appl. Biochem. Biotechnol. 166:484-520. https://doi.org/10.1007/s12010-011-9444-3

SLTC. 1996. Official methods of analysis. SLTC, Northampton.

Song, Y., S. Wu, Q. Yang, H. Liu, Y. Zeng, B. Shi. 2019. Factors affecting mass transfer of protease in pelt during enzymatic bating process. J. Leather Sci. Eng. 1:4. https://doi. org/10.1186/s42825-019-0007-7

Sumarlin, L. O., D. Mulyadi, Suryatna, \& Y. Asmara. 2013. Identification of potential lipase and cellulase on waste of skin fruit by fermentation. Jurnal Ilmu Pertanian Indonesia 18:159-166.

Taylor, M. M., M. B. Medina, J. Lee, L. P. Bumanlag, N. P. Latona, E. M. Brown, \& C. K. Liu. 2013. Treatment of hides with tara-modified protein products. J. Am. Leather Chem. Assoc. 108: 438 - 448.

Ullah, S., C. Ai, S. Huang, J. Zhang, L. Jia, J. Ma, W. Zhou, \& P. He. 2019. The responses of extracellular enzyme activities and microbial community composition under nitrogen addition in upland soil. PLoS ONE 14:1-19. https://doi. org/10.1371/journal.pone.0223026

Vaseghi, Z., G. D. Najafpour, S. Mohseni, \& S. Mahjoub. 2013. Production of active lipase by Rhizopus oryzae from sugarcane bagasse: Solid state fermentation in a tray bioreactor. Int. J. Food Sci. Technol. 48:283-289. https://doi. org/10.1111/j.1365-2621.2012.03185.x

Waseem A., S. Ali, \& S. W. Khalid. 2018. Enchanced production of an extracellular lipase by EMS and MMS - induced mutant strain of Rhizopus oligosporus EM-7 using almond meal as a basal substrate. Pak. J. Zool. 50:1929-1935. https:// doi.org/10.17582/journal.pjz/2018.50.5.1929.1935

Zengin G. \& A. Afsar. 2011. Use of natural fat emulsion in fatliquoring process and investigation of fatty spue formation. J. Am. Leather Chem. Assoc. 106:83-91. 